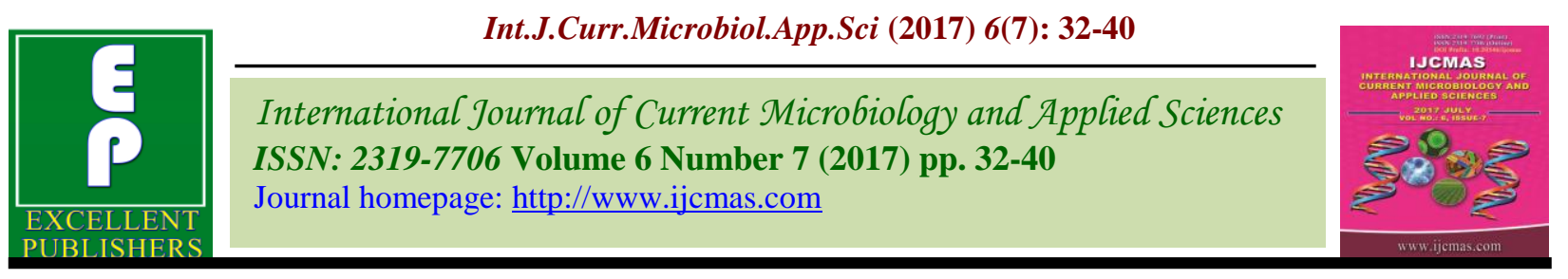

Review Article

https://doi.org/10.20546/ijcmas.2017.607.005

\title{
Integrated Nutrient Management in Fruit Production
}

\author{
Disket Dolker ${ }^{1 *}$, Parshant Bakshi ${ }^{1}$, V.K. Wali ${ }^{1}$, Stanzin Dorjey ${ }^{1}$, \\ Kiran Kour ${ }^{1}$ and Amit Jasrotia ${ }^{2}$
}
${ }^{1}$ Division of Fruit Science, Sher-e-Kashmir University of Agricultural Sciences and Technology of Jammu, Main Campus, Chatha-180009, Jammu, India
${ }^{2}$ Division of Plant pathology, Sher-e-Kashmir University of Agricultural Sciences and
Technology of Kashmir, Wadura Sopore, 193201, Kashmir, India
*Corresponding author

\section{A B S T R A C T}

The continuous use or excess supply of inorganic fertilizers as source of nutrient

\begin{tabular}{|l|}
\hline Key w or d s \\
Nutrient \\
management, \\
$\begin{array}{l}\text { Fruit production, } \\
\text { Environment and } \\
\text { Farming. }\end{array}$ \\
\hline Article Info \\
\hline $\begin{array}{l}\text { Accepted: } \\
\text { 04 June 2017 } \\
\text { Available Online: } \\
\text { 10 July } 2017\end{array}$ \\
\hline
\end{tabular}
in imbalanced proportion is also a problem, causing economic inefficiency, damage to the environment and in certain situations, harm the plants themselves and also to human being who consume them. On the other hand, increase in productivity of horticultural produce removes large amounts of essential nutrients from the soil. Without proper management, continuous production of crops reduces nutrient reserves in the soil. Another issue of great concern is the sustainability of soil productivity, as land began to be intensively exhausted to produce higher yields. Overtime, cumulative depletion decreases production, yield and soil fertility and lead to soil degradation. The new approach to farming often referred to as sustainable agriculture, seeks to introduce agricultural practices that are ecofriendly and maintain the long term ecological balance of soil ecosystem. The judicial use of organic inputs with inorganic is considered as the alternative source to meet the nutrient requirement of the crops.

\section{Introduction}

India has been bestowed with wide range of climate and physio-geographical conditions and as such is most suitable for growing various kinds of horticultural crops such as fruits, vegetables, flowers, nuts, spices and plantation crops (coco nut, cashew nut and cocoa). Its horticulture production has increased by 30 per cent in the last five years. This has placed India among the foremost countries in horticulture production, just behind China. During 2012-13, its contribution in the world production of fruits was $12.6 \%$. Total production of fruits during 2012-13 was 81.2 million tonnes (Anonymous, 2014). Though production of fruits has increased manifold over the last decade but there exists a gap between the demand and supply of fruits. The present fruit production in India meets only the $46 \%$ of the total demand. Thus there is strong need to increase the production and productivity through crop diversification and use of best horticultural techniques among which Integrated Nutrient Management is the one. 
As it is evident from the table 1 although the productivity of fruits is comparable to China and some other leading fruit producing countries of the world but India still lags behind USA and Indonesia in terms of productivity. This might be because of improper orchard management particularly nutrient management. The continuous use of chemicals fertilizers particularly NP\&K has impaired the soil fertility and decreased the factor productivity.

The increasing cost of fertilizers with poor purchasing capacity and their negative effect on soil health has led to intensified attempts to the use of bio-fertilizers and organic matter along with inorganic fertilizers. Integrated Nutrient Management (INM) is a system that helps to restore and sustain crop productivity, and also assists in checking the emerging micro-nutrient deficiencies.

Further, it brings economy and efficiency in the use of fertilizers. Integrated plant nutrient management can also be referred to as maintenance of soil fertility and plant nutrient supply to optimum level for sustaining the desired crop productivity through optimization of the benefits from all possible sources of plant nutrients in an integrated manner. It envisages the use of chemical fertilizers in conjunction with organic manures, green manures, crop residues, and legumes in a cropping system and locally available resources with objectives of sustaining high yield and ensuring environmental safety.

Objectives of integrated plant nutrient management are: (i) to reduce inorganic fertilizer requirement; (ii) to restore the organic matter in soil and to increase nutrient use efficiency; (iii) to maintain quality in terms of physical, chemical and biological properties of soil and (iv) to maintain the nutrient balance between the supplied nutrient and nutrient removed by plant and to improve soil health and productivity on sustainable basis.

\section{Goal of INM}

Sustainable agricultural production incorporates the idea that natural resources should be used to generate increased output and incomes, especially for low income groups without depleting the natural resource base. INM's goal is to integrate the use of all natural and man-made sources of plant nutrients, so that crop productivity increases in an efficient and environmentally benign manner, without sacrificing soil productivity of future generations (Gruhn et al., 2000). INM relies on a number of factors, including appropriate nutrient application and conservation and the transfer of knowledge about INM practices to farmers through extension personnel.

\section{Soil nutrient balance}

Sufficient and balanced application of organic and inorganic fertilizers is a major component of INM.

The continuous recycling of nutrients into and out of the soil is known as the nutrient cycle. The cycle involves complex biological and chemical interactions, some of which are not yet fully understood. A simplified version of this cycle of plant growth, based on Smaling (1993), is shown in figure 1.

\section{The plant nutrient balance system (Source: Smaling, 1993)}

The simplified cycle has two parts: "inputs" that add plant nutrients to the soil and "outputs" that export them from the soil largely in the form of agricultural products. Important input sources include inorganic fertilizers; organic fertilizers such as manure, plant residues, and cover crops; nitrogen generated by leguminous plants; and 
atmospheric nitrogen deposition. Nutrients are exported from the field through harvested crops and crop residues, as well as through leaching, atmospheric volatilization, and erosion. The difference between the volume of inputs and outputs constitutes the nutrient balance. Positive nutrient balances in the soils (occurring when nutrient additions to the soil are greater than the nutrients removed from the soil) could indicate that farming systems are inefficient and, in the extreme, that they may be polluting the environment. Negative balances could well indicate that soils are being mined and that farming systems are unsustainable over the long term. In the latter instance, nutrients have to be replenished to maintain agricultural output and soil fertility into the future.

\section{Constraints in use of organics complementary with mineral fertilizers}

\section{Convenience and advantages in use of} fertilizers

Though fertilizers are costly inputs in agriculture, they are 'concentrated' source of plant nutrients which can be formulated or tailored before or just prior to field application as per needs of the crops and can be applied with minimum transport and labour and at right time. Fertilizer use is high in irrigated crops, commercial crops and in peri-urban areas where awareness is high. The farmers are aware of the need for high nutrient use in high production areas under irrigated condition.

\section{Selective use of fertilizers and manures}

Fertilizer use is high in rice, wheat, sugarcane and cotton. Organic manures wherever available are invariably used in some vegetable crops like potato, onion, chillies, spices like ginger and turmeric, in cereals like rice, in commercial crops like sugarcane, cotton and fruit crop banana. Green manuring is very prominent in rice and sugarcane and farmyard manure is commonly applied in arid and semi-arid dry land areas where costly fertilizers are discouraged due to the risk associated with their use and also due to the need for water for irrigation/soil moisture for better utilization of the applied nutrients. Farmers are also aware of the need for organics in dry land agriculture where some sort of stability to production is ensured because of its possible role in soil structure improvement and moisture storage and supply. The farmers in India apply good amount of organic manure (FYM, compost, goat, poultry and pig manure) at some periodicity to regenerate the soil fertility after three to five years of cropping.

\section{Agro-ecological differences}

Organic manure use is high in arid and semiarid zones where rainfall/irrigation water or soil moisture is a limitation.

\section{Peri-urban/rural differences}

Developed market encourages farmers to use fertilizers and produce more under intensive system of cropping. Even small farmers use more fertilizers inputs, however in peri-urban areas, there is also possibility for use of agroindustrial or urban municipal wastes along with fertilizers to augment soil fertility. Farmers' in remote areas with poor infrastructure and without access to market but are aware of the benefits of fertilizer use locally available organic sources.

\section{Single multiple enterprises}

Farmers who have less number of cattle may have to depend solely or mainly on fertilizers whereas farmers who practice several occupations like cash and field crops, dairy or livestock, poultry, fisheries enterprise etc., 
have opportunities to use/recycle the wastes, manures preferentially and profitably without depending on costly purchased inputs.

\section{Land tenancy}

The farmers who take land on tenure basis try to harvest high yields using mineral fertilizers and irrigation to ensure rapid returns to cover the cost of renting the land and may ignore the use of organic manures especially in cereal crop production.

\section{Lack of organic materials}

Unavailability of organic materials especially animal manure and crop residues is a primary constraint in many areas.

\section{Competitive use of organic resources}

A very important example of competitive use is the use of cow dung as fuel because of the shortage of fuel wood. Similarly, crop straws or stalks like that of castor, red gram, and cotton are used as fuel. Crop residues are also very valuable animal feed. Sometimes poultry manure/droppings are mixed with other additives and used as fish or cattle feed.

\section{High cost of organic manures}

Cost of organic manures especially animal manures is high in peri-urban areas where these manures are preferentially used in ornamental gardens, lawns and home gardens in raising vegetable crops.

\section{Transport}

Because organic manures are bulky, it is not convenient to transport and to apply them in all crops in all seasons. So it is applied conveniently in sufficiently good amount in remunerative crops at 4-5 years interval especially in kharif crops.

\section{Pests, diseases and weeds}

Some believe that the organic manures may carry pests, pathogens and weed seeds and propagate them in the current or following crops.

\section{Current status of INM}

Keeping the importance of organic resources in view, a lot of research has been done on integrated nutrient management during last two decades in natural resource management (NRM) institutions and state agricultural universities. This research has led to:

Development of INM practices for major crops;

Understanding the enhanced role of organic manures in increasing input use efficiency due to their favourable effect on physical, chemical and biological condition of the soil;

Establishing the beneficial role of integrated use of organic manures in improving nutrient cycling in different production systems in various types of soils;

Beneficial role of INM in improving soil chemical, physical and biological quality for sustainable crop production; and

The work on INM has been compiled and published in the form of books/bulletins by several institutions.

\section{Challenges}

The promotion of integrated nutrient management in different parts of the world, and particularly in rural areas of developing countries where most of the poor live, will require a concerted effort by a multitude of actors. The following sections discuss the key components of a strategy for building 
appropriate institutions involved in research, extension, and participatory work on INM.

\section{Research}

The means to improve nutrient and soil fertility management may well differ in many parts of the world. Whatever steps can be taken will depend, in the first instance, on having adequate information on a wide range of topics dealing with the nutrient cycle. Even though some valuable agricultural research has been conducted in temperate regions, the research in tropical regions presents enormous challenges that will require the cooperation of both national and international agricultural research centers. For example, much more needs to be known about the role of micronutrients in many parts of Asia, where rice yields in irrigated areas appear to have leveled off despite increasing rates of NPK application (Gill 1995). Similarly, more needs to be known about whether constraints arising from a shortage of micronutrients are affecting production in the potentially rich soils of areas. Deriving such information may require a reorientation of ongoing research and trials as well as the initiation of research and monitoring efforts specifically intended to learn more about soil management under different conditions.

\section{Extension}

No single set of recommendations on plant nutrient application are appropriate for the diverse agricultural environments and economic conditions that exist in the world. Rather, farmers, with the aid of extension services, have to be given access to and choose the most appropriate and costeffective technologies for their particular circumstances. Farmers also need to participate in the development of these technologies and become knowledgeable about managing soil fertility and capturing the opportunities offered by their diverse environments. Successful INM adoption programs thus must enhance farmers' capacity to learn and break free from the conventional fix of one-way technology transfer from researcher to farmer (Deugd et al., 1997). Successful INM extension will also require greater monitoring and testing of plants and soils. Monitoring will help ensure that an environment conducive for optimal plant growth and crop yield can be established through nutrient application and soil reclamation. Where practical and available, testing techniques such as plant-nutrientdeficiency diagnosis, plant tissue analysis, biological comparison tests across soils, and chemical soil analysis are needed to help the farmer improve crop and soil management. Together, monitoring, testing, and nutrient application recommendations that reflect crop needs and soil nutrient levels can enable extension agents to help farmers overcome the limitations arising from harsh agroclimatic and soil conditions.

\section{Participation}

Participation is another key to more effective INM. The interaction of farmers, researchers, extension services, nongovernmental organizations (NGOs), and the private sector involved in the distribution system is vital to the proper evaluation and wider dissemination of traditional technologies and the development and adoption of new ones. Farmers need to play a more important role in technology development. Plant breeders, for example, often focus narrowly on increasing yields and disease resistance. But farmers have other concerns as well. In particular, farmers want modern varieties that generate high yields for crops with high consumer demand, save labor and reduce costs, and produce plants that resist drought, pests, and disease (Franzel and Van-Houten, 1992). New technologies should also take into account the 
diversity, food security, and other risk concerns of smallholder farmers.

Government has an important role to play in promoting policies that contribute to sustainable nutrient and soil fertility management. This role involves committing resources to national research and extension programs and creating an environment conducive to the adoption of sustainable and yield-improving technologies.

In effect the government's role will continue to change from one of supplying and distributing chemical fertilizers to one of regulating the market for plants and nutrients, both organic and inorganic.

The policy environment needed for the development of efficient markets will require investment in transport and communication infrastructure. Only when remote areas are sufficiently connected to markets can farmers have access to the critical inputs and technology necessary for augmenting and sustaining production and have the ability to sell their goods and services. In the meantime, less-developed regions should be supported temporarily with programs that help to conserve and recapitalize nutrient reserves and sustain soil fertility.

\section{Strategies}

\section{Recycling of crop residues and green manuring}

Management of crop residues is either through of the following 3 methods; removal, burning or incorporation into soil. Burning is a minor practice in India. Sidhu and Beri (1989) reported that in situ recycling of crop residues in rice-wheat rotation reduced grain yield of rice and wheat.

Therefore, most of the farmers recycle the crop residues not by choice but due to combine harvesting, burn the residue causing loss of precious organic matter, plant nutrients and environmental pollution.

Table.1 Major fruit producing countries in the world (2012-13)

\begin{tabular}{|l|l|l|l|}
\hline Country & Area in '000 ha & $\begin{array}{l}\text { Production in } \\
\text { '000 MT }\end{array}$ & $\begin{array}{l}\text { Productivity } \\
\text { in MT/ha }\end{array}$ \\
\hline China & 11834 & 137067 & 11.6 \\
\hline India & 6982 & 81285 & 11.6 \\
\hline Brazil & 2325 & 38369 & 16.5 \\
\hline United States of America & 1138 & 26549 & 23.3 \\
\hline Indonesia & 797 & 17744 & 22.3 \\
\hline Phillipines & 1240 & 16371 & 13.2 \\
\hline Mexico & 1257 & 15918 & 12.7 \\
\hline Turkey & 1103 & 14975 & 13.6 \\
\hline Spain & 1539 & 13996 & 9.1 \\
\hline Italy & 1126 & 13889 & 12.3 \\
\hline Others & 27925 & 270595 & 9.7 \\
\hline World & $\mathbf{5 7 2 6 5}$ & $\mathbf{6 4 6 7 5 8}$ & $\mathbf{1 1 . 3}$ \\
\hline
\end{tabular}

Source: Handbook of Horticulture Statistics-2014, Government of India, Ministry of Agriculture, New Delhi 
Fig.1 Soil nutrient balance

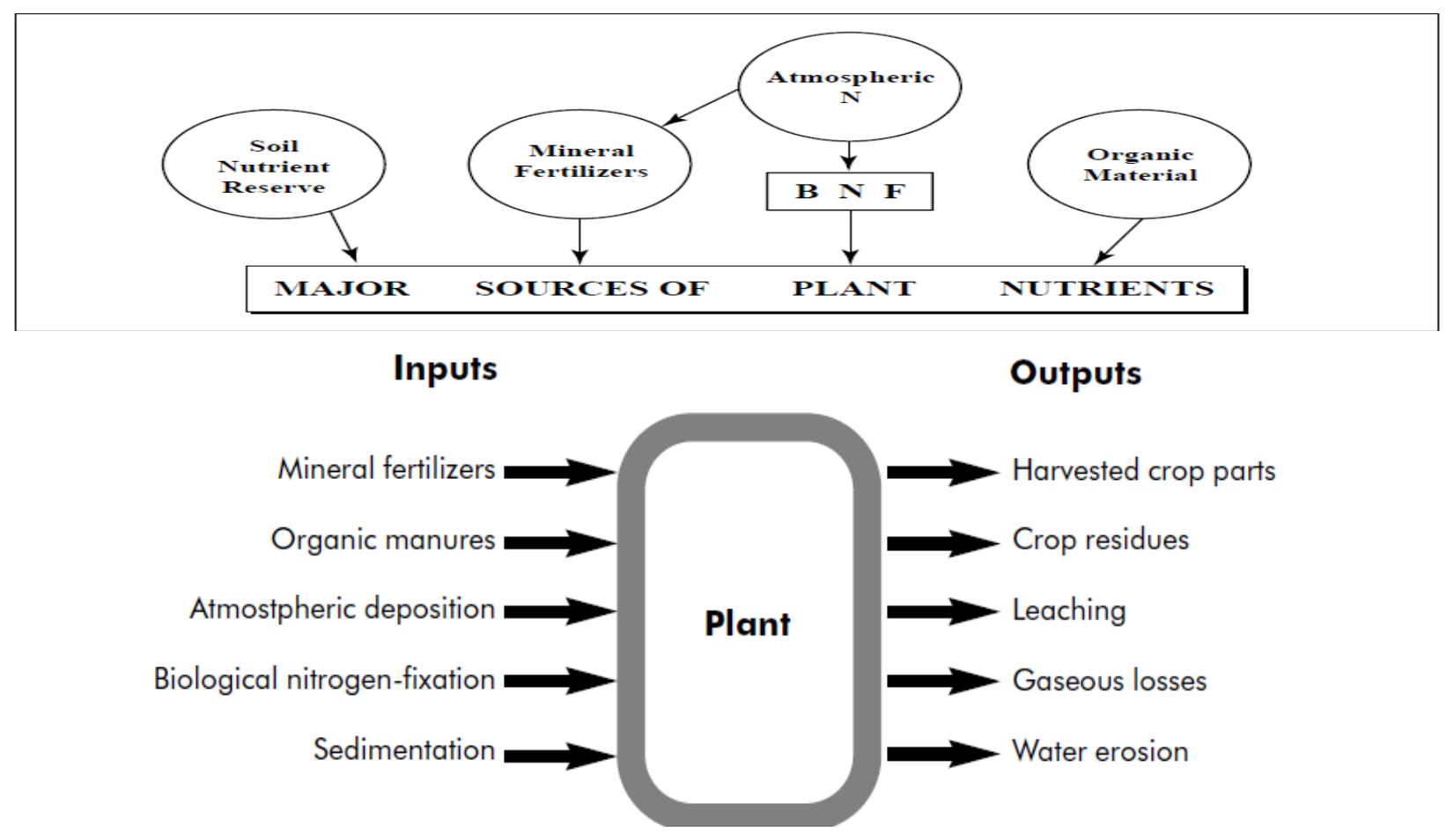

\section{Role of bio-fertilizers in INM under} intensive systems

Several studies clearly indicate that among the different types of bio-fertilizers available at present, Rhizobium is relatively more effective and widely used. Considering an average $\mathrm{N}$ fixation rate of $25 \mathrm{~kg} \mathrm{~N} / \mathrm{ha}$ per 500 $\mathrm{g}$ application of Rhizobium, it is expected that 1 tonne of Rhizobium inoculants will be equivalent to 50 tonnes of nitrogen. On the other hand, Azotobacter, which is used in non-legume crops has given inconclusive results. Similarly, Blue Green Algae (BGA) and Azolla have been reported to be effective only in certain traditional rice growing areas in the country. Meanwhile if BGA applied at $10 \mathrm{~kg} / \mathrm{ha}$ fixes $20 \mathrm{~kg} \mathrm{~N} / \mathrm{ha}$, then 1 tonne of BGA has an equivalent fertilizer value of 2 tonnes of nitrogen. The beneficial effect of the organisms like Azospirillum and Azotobacter in suppression of soil borne pathogenic diseases of crops is yet to be established on a pilot scale. Another important role of biofertilizers is liberation of growth substances, which promote germination and plant growth. Against the total anticipated biofertilizers demand of 1 million tonne in the country, the current supply position is very low ( $<10000$ tonnes). There are several constraints to effectively utilize and popularize the use of biofertilizers. Some of these constraints are:

Unlike mineral fertilizers, use of the biofertilizers is crop and location specific. A strain found ideal at one location may be ineffective at another location due to competition of native soil microbes, poor aeration, high temperature, soil moisture, acidity, salinity and alkalinity, presence of toxic elements etc;

Low shelf life of the microorganisms;

Unlike mineral fertilizers, bio-fertilizers need careful handling and storage; 
Lack of suitable carrier material, for restoration and longevity in actual field conditions.

In order to overcome the above-cited constraints and make bio-fertilizers an effective supplementary source of mineral fertilizers, these aspects need to be critically attended.

\section{General precautions}

Never mix zinc, iron or copper micronutrient fertilizers with phosphatic fertilizers as these elements are rendered less soluble.

Avoid excessive use of phosphorous as it adversely affects utilization of zinc, iron and copper.

Excess of iron adversely affects utilization of zinc and manganese; conversely excess of zinc, manganese and copper induces iron deficiency in crops. Thus mixing of iron containing fertilizers with zinc, manganese and copper fertilizers should be avoided. Further, over-use of micro-nutrients should also be avoided.

Excess of sulphur and copper induces molybdenum deficiency in crops. Thus application of sulphur and copper should be within recommended doses.

Excessive use of lime or liming material should be avoided as it induces zinc, iron, and manganese and boron deficiency.

\section{Constraints}

The major constrains for proper adoption and utilization of INM technology at farmer's level are listed below:

Farmers often have inadequate knowledge and funds, which compelled them to mis- purchase and mis-application of fertilizers. Most of the farmers are aware of fertilizers but do not use it in balanced proportion;

The linkage and interactions among researchers, extension services and NGO personnel are weak;

Degradation of lands due to intensive cropping/over exploitation by the enormous pressure of the ever increasing population;

Risks of water deficit in drought prone period are considered the most important deterrent to fertilizer use; and

During monsoon water erosion is a serious threat on soil fertility and productivity.

\section{Research gaps in INM}

Mismatching of INM practices developed at research stations with the farmers' resources and their practices;

INM recommendations for different crops are not based on soil testing and nutrient release behaviour of the manures;

Nutrient balance/flow analysis vis-à-vis soil fertility management practices with special reference to INM at farm level needs to be worked out;

Nutrient release characteristics of farm residues in relation to their quality to develop decision support systems;

Biofertilizers were not included as component of INM in many cases; and

Integrated Farming Systems (IFS) approach needs to be encouraged for sustaining livelihood in rural areas particularly for small and marginal farmers. 


\section{References}

Anonymous. 2014. Handbook on Horticulture Statistics 2014. Government of India, Ministry of Agriculture, Department of Agriculture and Cooperation, New Delhi, Pp. 1-48.

Deugd, M., Roling, N. and. Smaling. E.M.A. 1997. Facilitating integrated nutrient management: Towards a praxeology. Mimeo.

Franzel, S. and Van Houten, H. 1992. Research with farmers: Lessons from Ethiopia. Wallingford, UK: CAB International. Pp. 303.

Gill, G. J. 1995. Major natural resource management concerns in South Asia. Food, Agriculture, and the Environment Discussion Paper 8. IFPRI, Washington, DC.
Gruhn, P., Goletti, F. and Yudelman, M. 2000. Integrated nutrient management, soil fertility, and sustainable Agriculture: Current issues and future challenges. International Food Policy Research Institute, Washington, D.C., USA. 3-31 Pp.

Sidhu, B.S. and Beri, V. 1989. Effect of crop residue management on yield of different crops and soil properties. Biol Wastes, 27:15-27

Smaling, E. M. A. 1993. Soil nutrient depletion in Sub-Saharan Africa. In: The role of plant nutrients for sustainable food crop production in Sub-Saharan Africa, H. Van Reuler and W. H. Prims (Eds). Leidschendan, VKP, The Netherlands.

\section{How to cite this article:}

Disket Dolker, Parshant Bakshi, V.K. Wali, Stanzin Dorjey, Kiran Kour and Amit Jasrotia. 2017. Integrated Nutrient Management in Fruit Production. Int.J.Curr.Microbiol.App.Sci. 6(7): 32-40. doi: https://doi.org/10.20546/ijcmas.2017.607.005 